Original Research

\title{
Assessing 16 Polycyclic Aromatic Hydrocarbons (PAHs) in River Basin Water and Sediment Regarding Spatial-Temporal Distribution, Partitioning, and Ecological Risks
}

\author{
Yanan Chen, Caiyun Sun, Jiquan Zhang*, Feng Zhang \\ Natural Disaster Research Institute, School of the Environment, Northeast Normal University, \\ Changchun 130117, People's Republic of China
}

Received: 22 March 2017

Accepted: 11 July 2017

\begin{abstract}
This work investigated the distribution, partitioning, and ecological risks of 16 polycyclic aromatic hydrocarbons (PAHs) in water and sediment of the Yinma River Basin in China in normal, wet, and dry seasons. Sixteen PAHs were analyzed in 17 paired sets of water and sediment samples collected from the study area. The concentrations of PAHs in water and sediment showed spatial-temporal variations, the concentrations in water ranged from 167.6 to $373.9 \mathrm{ng} / \mathrm{L}$ with a mean value of $227.9 \mathrm{ng} / \mathrm{L}$ in the normal season, from 186.0 to $386.9 \mathrm{ng} / \mathrm{L}$ with a mean value of $281.6 \mathrm{ng} / \mathrm{L}$ in the wet season, and ranged from 147.0 to $315.9 \mathrm{ng} / \mathrm{L}$ with an average value of $218.6 \mathrm{ng} / \mathrm{L}$ in the dry season, while concentrations in sediment varied from 895.6 to $2,518.2 \mathrm{ng} / \mathrm{g}$ with a mean value of $1,739.4 \mathrm{ng} / \mathrm{g}$ in the normal season, from $1,233.0$ to $4,763.0 \mathrm{ng} / \mathrm{g}$ with a mean value of $2,122.6 \mathrm{ng} / \mathrm{g}$ in the wet season, and ranged from 914.2 to $5,678.5 \mathrm{ng} / \mathrm{g}$ with an average value of $1,943.7 \mathrm{ng} / \mathrm{g}$ in the dry season. Partitioning of PAHs in water and sediment was studied and the result showed that PAHs tend to absorb in sediment. Ecological risk assessments were conducted based on the species-sensitivity distribution (SSD) model, with results suggesting that ecological risks of individual PAHs in water and sediment were little, and the multiple congeners of PAHs in sediment from some sampling sites had ecological risks. Primary sources of 16 PAHs in water and sediment were identified with isomer ratios, and results indicated that primary sources of PAHs in water were identified as a mixture pattern of petroleum and combustion sources, and in sediment were identified as a mixture pattern of petroleum and grass, wood and coal combustion sources.
\end{abstract}

Keywords: polycyclic aromatic hydrocarbons, partitioning, source identification, ecological risks, Yinma River Basin

*e-mail: zhangjq022@nenu.edu.cn 


\section{Introduction}

Polycyclic aromatic hydrocarbons (PAHs) are a group of organic chemicals containing two or more aromatic rings without any heteroatoms or substituents [1-6], and prevalently exit in the environment, which are derived from nature and anthropogenic processes such as incomplete combustion, industrial incineration, wastewater discharge, vehicular emissions, and uncontrolled spills [7-9]. PAHs have toxicity of erotogenesis, carcinogenicity, and mutagenicity, and their toxicity is even greater in aquatic environments [10-11]. PAH pollution in aquatic environments has drown worldwide attention as their effects are usually widespread and permanent [12]. Sixteen special PAHs are maintained on a priority pollutant list by the United States Environmental Protection Agency (USEPA) [13]. Due to their lipophilicity, high octanol-water partition coefficients, and long-range transport, once PAHs enter an aquatic environment they may remain in water or accumulate in organisms and migrate as water flows. Meanwhile, sediment acts as a local scale collector for environmental contaminants [14-15]. PAHs adsorbed on the sediment would be retained in sediment for a long time [16] or released into water, causing secondary pollution [17-18]. Therefore, it is quite necessary to routinely monitor concentration levels of PAHs in an aquatic environment and evaluate their potential risks [13, 19-20].

The Yinma River Basin $\left(43^{\circ} 0^{\prime} \mathrm{N}-45^{\circ} 0^{\prime} \mathrm{N}, 124^{\circ} 30^{\prime} \mathrm{E}\right.$ - $\left.126^{\circ} 0^{\prime} \mathrm{E}\right)$ is located in the middle of Jilin Province in China, which provides domestic water for 8 million residents and irrigates farmland in the region. The area has a north temperate continental monsoon climate and the average annual temperature is approximately $4.9^{\circ} \mathrm{C}$. In the Changchun site the annual mean precipitation is $582.2 \mathrm{~mm}$. The precipitation between June and September is $451.2 \mathrm{~mm}$, which accounts for $77.5 \%$ of the whole year. The Yinma Basin receives a great amount of industrial discharge, vehicular emissions, agricultural runoff, and the results of oil-related activities. In fact, these anthropogenic activities possibly result in pollution of PAHs in environments connected with water. However, there has been little information on concentration levels and distribution of PAHs in aquatic environments of the Yinma Basin.

Accordingly, the aims of this study are to investigate concentration levels and spatial-temporal distribution of PAHs in water and sediment from the Yinma in normal and wet seasons, to illustrate the partitioning of PAHs in a sediment-water system, to assess ecological risks based on a species-sensitivity distribution (SSD) model, and to identify possible sources of PAHs in water and sediment with isomer ratios. This work aims to provide valuable information for pollution control and quality criteria.

\section{Materials and Methods}

\section{Sampling}

Seventeen paired sets of water and sediment samples were collected from the basin and its five branches in May and August 2015 (Fig. 1). The figure shows that the sample sites of 1 to 10 belong to the upper reach, 11 to 13 belong to the middle reach, and 14 to 17 belong to the lower reach. Water samples (below 0.5-1 m) were collected in cleaned glass bottles with cap, and riparian sediment samples were collected using a stainless steel grab sampler and placed in dark polytetrafluoroethylene bags. GPS was used for locating the sampling positions. The samples were taken from the same locations in normal and wet seasons. All samples were transported to a laboratory and analyzed within $24 \mathrm{~h}$.

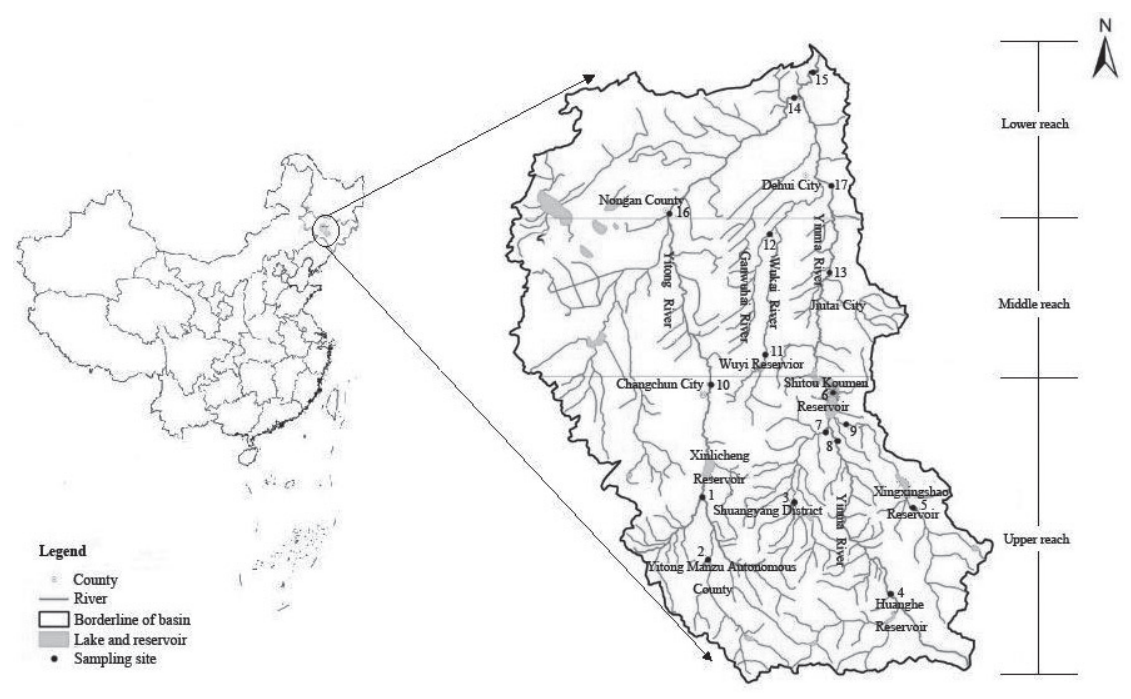

Fig. 1. Locations of Yinma River Basin and sampling sites. Note: 1-YT2 2-YT1 3-SY1 4-YM1 5-CL1 6-YM3 7-SY2 8-YM2 9-CL2 10YT3 11-WK1 12GW1 13-YM4 14-YT5 15-YM6 16-YT4 17-YM5. 


\section{Extraction Methods}

We analyzed 16 PAHs recommended as priority pollutants by the USEPA.

\section{Water Samples}

The 16 PAHs in water samples were extracted using a solid phase extraction (SPE) system (ASE-12, Tianjin Automatic Science Instrument Co., China). A C18 cartridge (500 mg, $6 \mathrm{~mL}$, Agela Technologies Inc., USA) was prewashed successively with $6 \mathrm{~mL}$ of dichloromethane (DCM), $6 \mathrm{~mL}$ of methanol, and $6 \mathrm{~mL}$ of deionized water. Then $2 \mathrm{~L}$ of each water sample filtered with $0.45 \mu \mathrm{m}$ filters passed through the prewashed cartridge (Cleanert S C18-SPE, Agela Technologies Inc., USA) at a constant rate of $5 \mathrm{~mL} / \mathrm{min}$ under vacuum. Then the cartridge was respectively eluted with $10 \mathrm{~mL}$ of DCM and the volume of the extracts was collected and concentrated to near dryness using a rotary vacuum evaporation apparatus (RE-52AA, Shanghai Yarong Inc., China) and adjusted to $1 \mathrm{~mL}$ with DCM for gas chromatography (GC) analysis [21]. Dichloromethane (DCM) and methanol were all purchased from Sinopharm Chemical Reagent Co., Ltd.

\section{Sediment Samples}

Each sediment sample was freeze-dried, crushed into fine powder, and passed through a $2 \mathrm{~mm}$ sieve. Each sediment sample $(2 \mathrm{~g})$ was mixed with anhydrous sodium sulfate $(1: 1 / \mathrm{w}: \mathrm{w})$ and extracted in an ultrasonic bath with $20 \mathrm{~mL}$ of $\mathrm{n}$-hexane/DCM (1:1/v:v) for 20 minutes (repeated three times). The extracts were mixed and reduced to $1 \mathrm{~mL}$ with a rotary vacuum evaporation apparatus (RE52AA, Shanghai Yarong Inc., China), and then passed through a silica chromatography column (Cleanert Florisil $1,000 \mathrm{mg} / 6 \mathrm{~mL}$ cartridge, Agela Technologies Inc., USA). Then the column was eluted with a mixture $(30 \mathrm{~mL})$ of $\mathrm{n}$-hexane and DCM $(1: 1 / \mathrm{v}: \mathrm{v})$, concentrated to near dryness with a rotary vacuum evaporation apparatus and rinsed with $10 \mathrm{~mL}$ of DCM. The elute was reduced to $1 \mathrm{~mL}$ by rotary evaporator and transferred to $2 \mathrm{~mL}$ capped Teflon-lined vials for gas chromatograph (GC) analysis [22].

\section{Gas Chromatograph Analysis}

The samples were analyzed using a GC system (Clarus 680, PerkinElmer Inc., USA) equipped with a flame ionization detector. A $30 \mathrm{~m} \times 0.25 \mathrm{~mm} \times 0.25 \mu \mathrm{m}$ HP-5 capillary column was used for separating target compounds. The injection mode was splitless, and sample volume was $1 \mu \mathrm{L}$. High-purity helium was used as a carrier gas at a constant flow rate of $1 \mathrm{~mL} / \mathrm{min}$. The chromatographic conditions were $80^{\circ} \mathrm{C}$ (maintained for $1 \mathrm{~min}$ ), ramping up from 80 to $255^{\circ} \mathrm{C}$ at $15^{\circ} \mathrm{C} \mathrm{min}{ }^{-1}$ (maintained for $1 \mathrm{~min}$ ), from 255 to $265^{\circ} \mathrm{C}$ at $2.5^{\circ} \mathrm{C} \mathrm{min}{ }^{-1}$ (maintained for $1 \mathrm{~min}$ ), and from 265 to $300^{\circ} \mathrm{C}$ at $2.5^{\circ} \mathrm{C}$ $\mathrm{min}^{-1}$ (maintained for $5 \mathrm{~min}$ ).

\section{Quality Control}

All data were subjected to quality control procedures. Quantifications of PAHs were done using external standards, with correlation coefficients for calibration curves all higher than 0.993 . The recovery experiments were undertaken by spiking 16 PAH standard solutions with water and sediment samples. Five parallel experiments were conducted, the results indicating that recoveries for water samples were $63-98 \%$, and for sediment samples were $94-111 \%$. The detection limits ranged from $0.12 \mathrm{ng} / \mathrm{L}$ to $1.07 \mathrm{ng} / \mathrm{L}$ for water and $1.5 \mathrm{ng} / \mathrm{g}$ to $9.3 \mathrm{ng} / \mathrm{g}$ for sediment. The chromatogram of $16 \mathrm{PAH}$ compounds is presented in Fig. 2.

\section{Other Analyses}

A small amount of each sediment sample was used to analyze total organic carbon (TOC) content in sediment with a total organic carbon analyzer (TOC-VCPN, Shimadzu Corp., Japan).

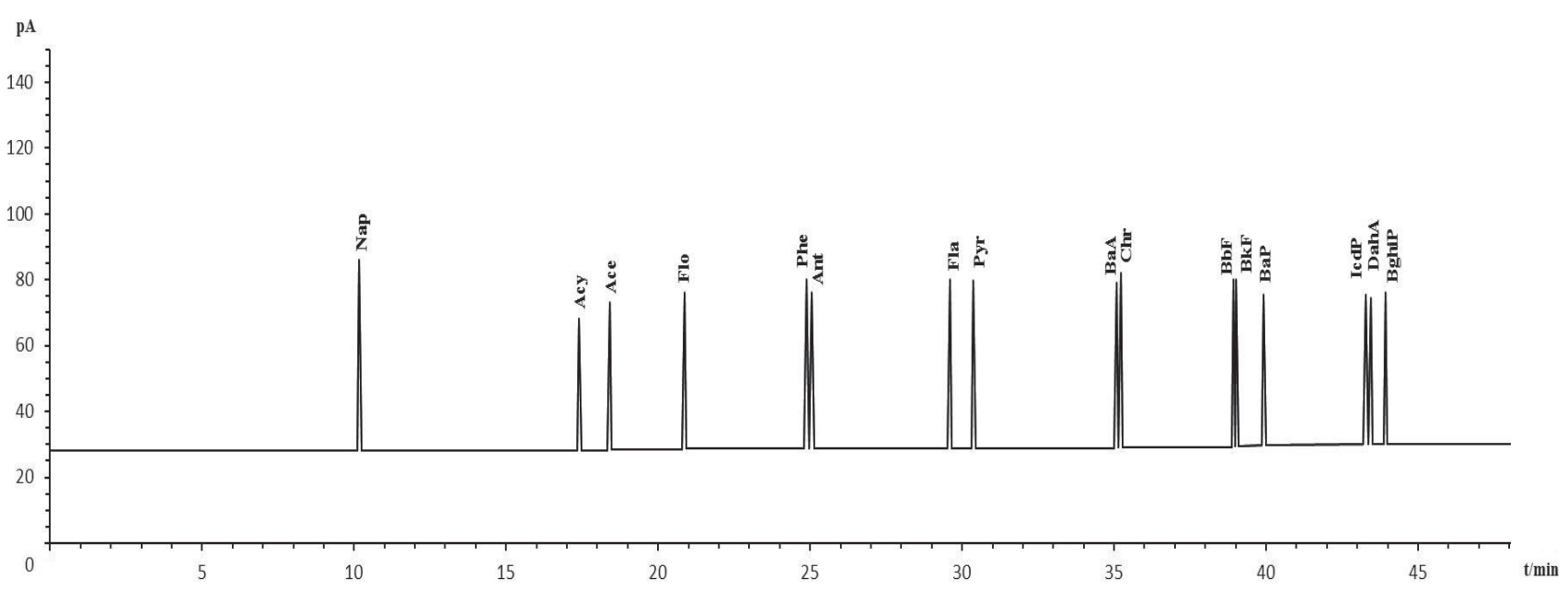

Fig. 2. Chromatogram of 16 PAH compounds. 
Table 1. PAH concentrations in water (a) and sediment (b).

\begin{tabular}{|c|c|c|c|c|c|c|c|c|c|c|c|c|}
\hline \multirow[b]{2}{*}{$\mathrm{a}$} & \multicolumn{4}{|c|}{ Normal season } & \multicolumn{4}{|c|}{ Wet season } & \multicolumn{4}{|c|}{ Dry season } \\
\hline & $\begin{array}{c}\text { Min } \\
\text { (ng/L) }\end{array}$ & $\begin{array}{c}\text { Max } \\
\text { (ng/L) }\end{array}$ & $\begin{array}{l}\text { Mean } \\
\text { (ng/L) }\end{array}$ & $\mathrm{CV} \%$ & $\begin{array}{c}\text { Min } \\
(\mathrm{ng} / \mathrm{L})\end{array}$ & $\begin{array}{c}\operatorname{Max} \\
(\mathrm{ng} / \mathrm{L})\end{array}$ & $\begin{array}{l}\text { Mean } \\
\text { (ng/L) }\end{array}$ & $\mathrm{CV} \%$ & $\begin{array}{c}\text { Min } \\
(\mathrm{ng} / \mathrm{L})\end{array}$ & $\begin{array}{c}\operatorname{Max} \\
\text { (ng/L) }\end{array}$ & $\begin{array}{l}\text { Mean } \\
\text { (ng/L) }\end{array}$ & $\mathrm{CV} \%$ \\
\hline Nap & 31.8 & 147.6 & 77.2 & 41.0 & 19.2 & 152.7 & 72.9 & 44.9 & 10.2 & 159.3 & 67.2 & 61.2 \\
\hline Ace & ND & 28.7 & 12.6 & 66.6 & ND & 33.8 & 9.7 & 95.7 & ND & 47.0 & 12.1 & 105.7 \\
\hline Acy & ND & ND & ND & ND & 10.2 & 43.1 & 21.2 & 48.8 & ND & ND & ND & ND \\
\hline Flo & ND & 38.0 & 20.2 & 48.0 & 4.4 & 40.8 & 22.6 & 53.5 & ND & 44.2 & 19.8 & 67.3 \\
\hline Phe & 19.4 & 87.4 & 46.9 & 37.2 & 16.3 & 102.2 & 50.5 & 50.8 & 10.1 & 95.2 & 46.4 & 62.1 \\
\hline Ant & ND & 11.3 & 4.3 & 99.0 & ND & 11.8 & 6.5 & 61.6 & ND & 14.4 & 5.1 & 105.1 \\
\hline Fla & ND & 8.9 & 3.0 & 115.4 & 3.6 & 9.7 & 6.3 & 33.0 & ND & 9.8 & 3.6 & 99.7 \\
\hline Pyr & ND & 25.3 & 12.7 & 67.1 & ND & 19.7 & 13.4 & 50.3 & ND & 24.3 & 12.7 & 54.8 \\
\hline $\mathrm{BaA}$ & ND & 11.6 & 3.0 & 123.1 & ND & 23.2 & 8.4 & 85.3 & ND & 15.3 & 4.4 & 124.5 \\
\hline Chr & ND & 37.6 & 17.4 & 51.3 & ND & 37.2 & 15.1 & 70.5 & ND & 39.5 & 14.3 & 88.4 \\
\hline $\mathrm{BbF}$ & ND & ND & ND & ND & ND & 46.2 & 12.0 & 106.2 & ND & ND & ND & ND \\
\hline $\mathrm{BkF}$ & ND & 35.3 & 13.4 & 86.3 & ND & 39.8 & 20.1 & 54.6 & ND & 49.2 & 16.9 & 98.0 \\
\hline $\mathrm{BaP}$ & ND & 3.3 & 0.5 & 218.0 & ND & 19.0 & 2.8 & 182.5 & ND & 3.1 & 0.9 & 131.5 \\
\hline DahA & ND & 29.1 & 13.2 & 71.7 & 8.3 & 28.7 & 16.4 & 32.1 & ND & 27.4 & 11.7 & 78.1 \\
\hline IcdP & ND & 11.4 & 3.7 & 117.3 & ND & 9.5 & 3.9 & 84.2 & ND & 13.2 & 3.5 & 130.6 \\
\hline BghiP & ND & ND & ND & ND & ND & ND & ND & ND & ND & ND & ND & ND \\
\hline$\sum$ PAHs & 167.6 & 373.9 & 227.9 & 23.2 & 186.0 & 386.9 & 281.6 & 17.4 & 147.0 & 315.9 & 218.6 & 25.3 \\
\hline
\end{tabular}

\begin{tabular}{|c|c|c|c|c|c|c|c|c|c|c|c|c|}
\hline \multirow[b]{2}{*}{ b } & \multicolumn{4}{|c|}{ Normal season } & \multicolumn{4}{|c|}{ Wet season } & \multicolumn{4}{|c|}{ Dry season } \\
\hline & $\begin{array}{c}\text { Min } \\
\text { (ng/g) }\end{array}$ & $\begin{array}{c}\text { Max } \\
\text { (ng/g) }\end{array}$ & $\begin{array}{l}\text { Mean } \\
(\mathrm{ng} / \mathrm{g})\end{array}$ & CV\% & $\begin{array}{c}\mathrm{Min} \\
(\mathrm{ng} / \mathrm{g})\end{array}$ & $\begin{array}{c}\operatorname{Max} \\
\text { (ng/g) }\end{array}$ & $\begin{array}{l}\text { Mean } \\
\text { (ng/g) }\end{array}$ & $\mathrm{CV} \%$ & $\begin{array}{c}\text { Min } \\
(\mathrm{ng} / \mathrm{g})\end{array}$ & $\begin{array}{c}\text { Max } \\
\text { (ng/g) }\end{array}$ & $\begin{array}{l}\text { Mean } \\
\text { (ng/g) }\end{array}$ & $\mathrm{CV} \%$ \\
\hline Nap & 109.2 & 1096.3 & 636.5 & 37.7 & 129.3 & 3672.2 & 973.0 & 83.3 & 145.8 & 4245.2 & 825.1 & 112.7 \\
\hline Ace & ND & 5.7 & 1.3 & 180.5 & ND & 6.4 & 1.4 & 134.4 & ND & 10.4 & 1.8 & 191.6 \\
\hline Acy & 26.7 & 211.7 & 106.4 & 53.5 & 27.2 & 222.0 & 83.0 & 55.2 & 14.6 & 225.7 & 76.7 & 84.8 \\
\hline Flo & 13.3 & 85.4 & 48.9 & 41.0 & 11.5 & 109.9 & 47.9 & 61.9 & 5.6 & 94.5 & 41.7 & 61.0 \\
\hline Phe & 153.7 & 964.6 & 556.2 & 45.3 & 121.8 & 936.3 & 519.5 & 41.7 & 179.8 & 1165.3 & 564.3 & 50.8 \\
\hline Ant & ND & 39.4 & 13.7 & 89.5 & ND & 78.4 & 30.5 & 74.1 & ND & 86.5 & 29.7 & 97.3 \\
\hline Fla & 43.2 & 319.3 & 150.3 & 55.1 & 39.2 & 361.3 & 152.2 & 63.7 & 24.6 & 411.3 & 163.6 & 76.9 \\
\hline Pyr & 2.6 & 27.2 & 16.8 & 42.4 & 5.2 & 39.3 & 15.4 & 58.1 & 4.3 & 35.4 & 15.4 & 58.4 \\
\hline $\mathrm{BaA}$ & ND & 79.9 & 20.3 & 100.3 & 6.5 & 56.7 & 22.4 & 60.5 & ND & 46.1 & 19.8 & 90.1 \\
\hline Chr & 2.9 & 155.4 & 37.6 & 96.1 & 12.2 & 109.3 & 54.9 & 59.7 & 6.5 & 155.4 & 56.4 & 79.6 \\
\hline $\mathrm{BbF}$ & ND & 87.4 & 26.5 & 106.5 & 16.3 & 177.3 & 77.0 & 54.7 & 11.6 & 184.6 & 75.0 & 74.8 \\
\hline $\mathrm{BkF}$ & ND & 63.2 & 29.2 & 66.4 & 11.2 & 45.4 & 28.1 & 36.5 & ND & ND & ND & ND \\
\hline $\mathrm{BaP}$ & 5.7 & 80.2 & 24.0 & 69.0 & 9.2 & 97.4 & 38.1 & 64.5 & 7.4 & 166.4 & 51.9 & 71.5 \\
\hline DahA & ND & 84.7 & 16.5 & 120.4 & ND & 72.2 & 33.9 & 63.2 & ND & 54.2 & 22.4 & 84.5 \\
\hline IcdP & ND & 78.2 & 29.9 & 73.4 & ND & 52.2 & 23.4 & 68.5 & ND & ND & ND & ND \\
\hline BghiP & ND & 87.3 & 25.3 & 99.8 & ND & 76.1 & 22.0 & 107.2 & ND & ND & ND & ND \\
\hline$\sum$ PAHs & 895.6 & 2518.2 & 1739.4 & 24.5 & 1233.0 & 4763.0 & 2122.6 & 39.0 & 914.2 & 5678.5 & 1943.7 & 53.6 \\
\hline
\end{tabular}

ND: not detected; CV: coefficient of variation

All the data kept a valid decimal. 


\section{Results and Discussion}

\section{Spatial-Temporal Distribution of PAHs in Water and Sediment}

\section{PAHs in Surface Water}

Table 1 summarizes the statistical results of the 16 PAH concentrations measured in water and sediment. The concentrations of total dissolved PAHs in water ranged from 167.55 to $373.91 \mathrm{ng} / \mathrm{L}$ with an average value of $227.94 \mathrm{ng} / \mathrm{L}$ in normal season and from 186.01 to $386.89 \mathrm{ng} / \mathrm{L}$ with an average value of $281.58 \mathrm{ng} / \mathrm{L}$ in wet season, respectively compared with our previous work in the dry season [23] - in which the PAHs in water ranged from 147.03 to $315.87 \mathrm{ng} / \mathrm{L}$ with an average value of $218.62 \mathrm{ng} / \mathrm{L}$. There was a significant seasonal variation in concentrations of total PAHs in the water phase across this study area, and the concentrations of almost every station in the wet season was higher than in normal season (except for GW1 and WK1). In the dry season, the concentrations of almost all the stations were lower than in the normal (except for seven sampling sites) and wet (except for YM2, YT3 and GW1) seasons. But an unremarkable difference was observed. The composition pattern of PAHs in water is shown in Fig. 3. It is clear that light PAHs are the most abundant in three seasons. Heavy PAH concentrations are the lowest in three seasons.

The spatial distribution of the average concentrations of PAHs in water and sediment for three seasons is presented in Fig. 4. As shown in Fig. 4, the normal season sees a relatively high concentration of PAHs in water as observed at site GW1 (373.91 ng/L). This site, located in the middle and lower reaches of the Yinma, is located
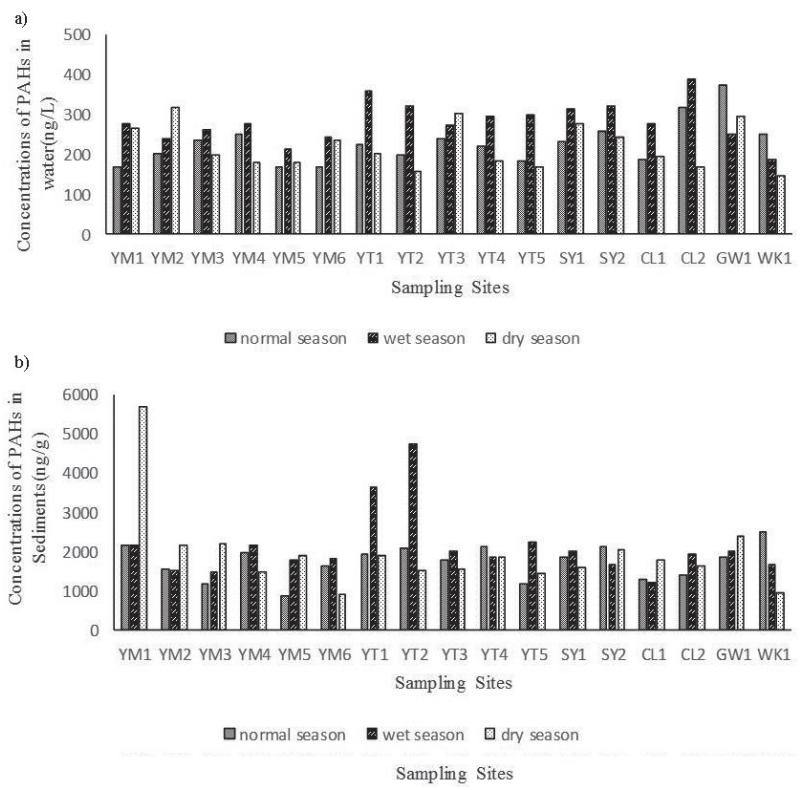

Fig. 4. Spatial distribution of total PAHs in the water a) and sediment $b$ ) in normal and wet seasons.

under a bridge that sees heavy vehicle traffic daily. And because a lot of farmland surrounds the sampling site, the concentrations of PAHs at GW1 are closely related to road dust and vehicle emissions. In addition, concentrations of PAHs in CL2 $(318.45 \mathrm{ng} / \mathrm{L})$ were relatively high. There were main roads and farmlands in the vicinity of the sampling site. In the wet season, the concentration of PAHs was high in site CL2 (386.89 ng/L) and YT1 (359.15 ng/L), followed by SY2 (320.59 $\mathrm{ng} / \mathrm{L})$, YT2 (320.6 ng/L), SY1 (315.13 ng/L), YT5 (298.12 ng/L), and
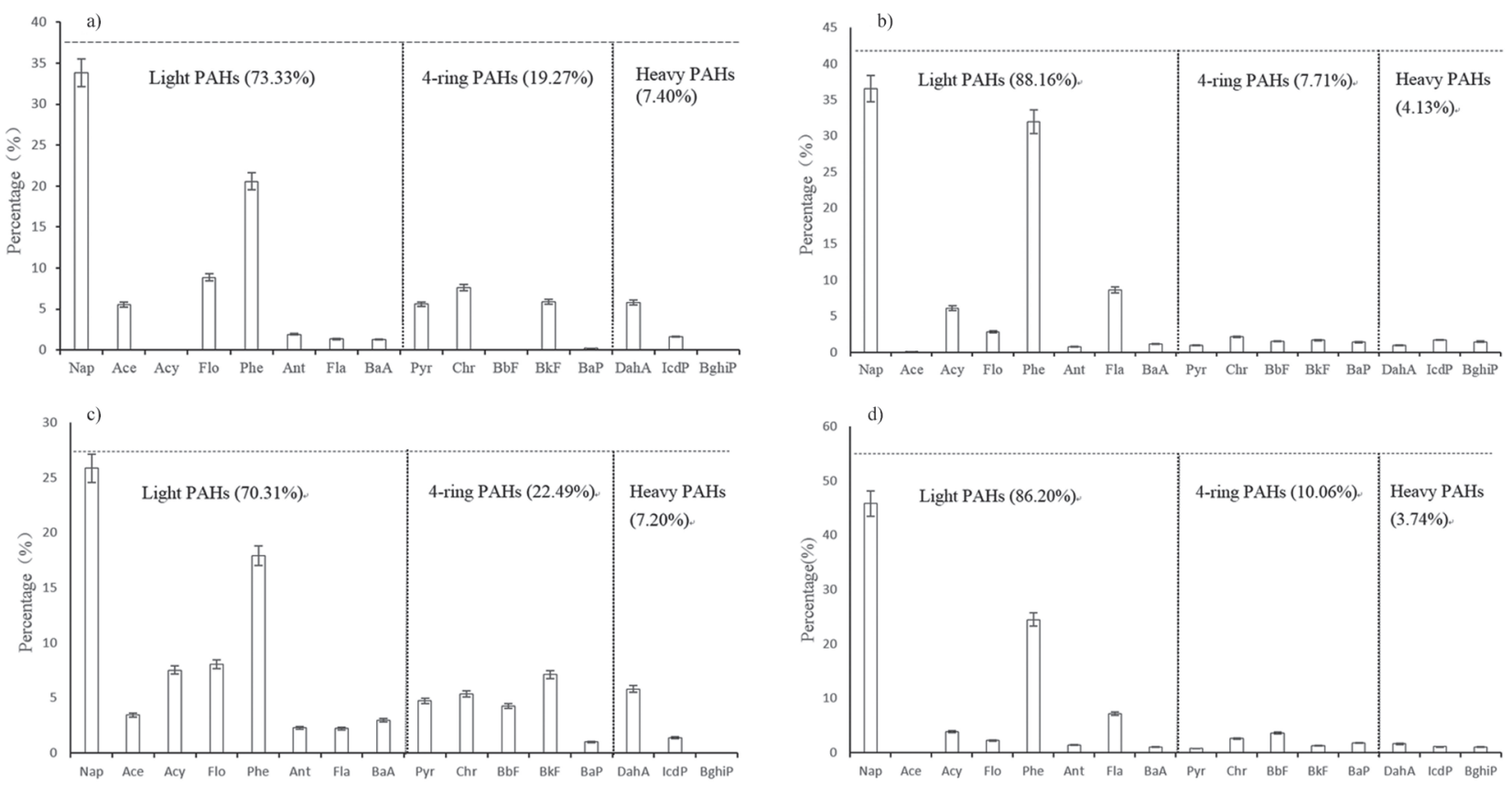

Fig. 3. Compositional pattern of PAHs in normal season water a), normal season sediment b), wet season water c), and wet season sediment d). 
Table 2. Total organic carbon (TOC) contents of sediment samples in normal and wet seasons (\%).

\begin{tabular}{|c|c|c|c|c|c|c|c|c|c|c|c|c|c|c|c|c|c|}
\hline Sites & YM1 & YM2 & YM3 & YM4 & YM5 & YM6 & YT1 & YT2 & YT3 & YT4 & YT5 & SY1 & SY2 & CL1 & CL2 & GW1 & WK1 \\
\hline $\begin{array}{c}\text { Normal } \\
\text { season }\end{array}$ & 15.1 & 13.3 & 13.6 & 17.2 & 12.6 & 14.2 & 16.2 & 13.9 & 16.4 & 15.4 & 19.6 & 18.7 & 15.6 & 12.3 & 9.7 & 14.5 & 10.9 \\
\hline $\begin{array}{c}\text { Wet } \\
\text { season }\end{array}$ & 19.6 & 17.3 & 13.5 & 11.1 & 10.5 & 12.1 & 10.3 & 11.1 & 14.3 & 16.2 & 10.5 & 13.2 & 15.7 & 13.3 & 9.9 & 11.5 & 13.1 \\
\hline
\end{tabular}

All the data kept a valid decimal.

YT4 (293.74 ng/L), and all these sampling sites are adjacent to the farmland and roads except for sites SY1, SY2, and YT4. In dry season, a relatively high concentration of PAHs in water was observed at sites YM2 (315.87 ng/L), YT3 (303.53 ng/L), and GW1 (296.85 ng/L), followed by SY1 (275.23 ng/L) and YM1 (267.19 ng/L). Sampling sites YM2, YT3, and YM1 are adjacent to the road and YM2 is adjacent to farmland.

\section{PAHs in Sediment}

The concentrations of total PAHs in sediment ranged from 895.64 to $2,518.17 \mathrm{ng} / \mathrm{g}$ with an average value of $1,739.4 \mathrm{ng} / \mathrm{g}$ in the normal season, and from $1,232.99$ to $4,762.97 \mathrm{ng} / \mathrm{g}$ with an average value of $2,122.57 \mathrm{ng} / \mathrm{g}$ in the wet season. Compared with our previous work in the dry season (in which the PAHs in sediment ranged from 914.17 to $5,678.46 \mathrm{ng} / \mathrm{g}$, with an average value of $1,943.7 \mathrm{ng} / \mathrm{g}$ ), there was a significant seasonal variation in concentrations of total PAHs in sediment across the study area. The concentrations of almost every station in the wet season were higher than in the normal season (except for YM2, YT4, SY2, CL1, and WK1). In the dry season the concentrations of sampling sites YM1, YM2, YM3, YM5, CL1, and GW1 were higher than in normal and wet seasons, and sites YM4, YM6, YT1, YT2, YT3, SY1, and WK1 were lower than the normal and wet seasons. The composition pattern of PAHs in sediment was shown in Fig. 3. It was clear that light PAHs were the most abundant in three seasons. Heavy PAH concentrations were the lowest in three seasons.

As shown in Fig. 4, in the normal season we observed a relatively high concentration of PAHs in sediment at site WK1 $(2,518.17 \mathrm{ng} / \mathrm{g})$, followed by

Table 3. Comparison of observed and predicted equilibrium partitioning coefficient of PAHs in normal and wet seasons.

\begin{tabular}{|c|c|c|c|c|c|c|}
\hline \multirow[b]{2}{*}{ PAHs } & \multirow[b]{2}{*}{$\log K_{\mathrm{ow}}{ }^{\mathrm{a}}$} & \multirow[b]{2}{*}{$\log K_{\mathrm{oc}}^{\mathrm{a}}$} & \multicolumn{2}{|c|}{ Normal season } & \multicolumn{2}{|c|}{ Wet season } \\
\hline & & & $\begin{array}{l}\log K_{o c}, \\
\text { (mean) }\end{array}$ & $\begin{array}{c}\Delta \log K_{\text {oc }} \\
\text { (obs-pred) }\end{array}$ & $\begin{array}{l}\log K_{o c}, \\
\text { (mean) }\end{array}$ & $\begin{array}{c}\Delta \log K_{\text {oc }} \\
\text { (obs-pred) }\end{array}$ \\
\hline Nap & 3.3 & 3.1 & 1.8 & -1.4 & 2.0 & -1.2 \\
\hline Ace & 4.0 & 3.5 & 0.5 & -3.0 & 0.2 & -3.3 \\
\hline Acy & 3.9 & 3.4 & - & - & 1.5 & -2.0 \\
\hline Flo & 4.2 & 3.7 & 1.2 & -2.5 & 1.2 & -2.5 \\
\hline Phe & 4.6 & 4.3 & 1.9 & -2.4 & 1.9 & -2.4 \\
\hline Ant & 4.5 & 4.3 & 1.3 & -3.0 & 1.4 & -2.9 \\
\hline Fla & 4.2 & 3.7 & 2.1 & -1.6 & 2.2 & -1.5 \\
\hline $\mathrm{BaA}$ & 5.8 & 5.3 & 0.9 & -4.4 & 0.8 & -4.5 \\
\hline Pyr & 4.9 & 4.7 & 1.5 & -3.2 & 0.9 & -3.8 \\
\hline $\mathrm{Chr}$ & 5.9 & 5.4 & 1.0 & -4.5 & 1.2 & -4.3 \\
\hline $\mathrm{BbF}$ & 5.8 & 5.4 & - & - & 1.0 & -4.3 \\
\hline $\mathrm{BkF}$ & 6.0 & 5.6 & 1.2 & -4.4 & 1.0 & -4.5 \\
\hline $\mathrm{BaP}$ & 6.0 & 5.6 & 1.8 & -3.9 & 1.6 & -4.1 \\
\hline IcdP & 6.5 & 6.2 & 1.0 & -5.2 & 1.1 & -5.1 \\
\hline DahA & 7.0 & 6.6 & 1.5 & -5.1 & 1.6 & -5.1 \\
\hline BghiP & 6.5 & 6.9 & - & - & - & - \\
\hline
\end{tabular}

obs: observed; pred: predicted ${ }^{\mathrm{a}} \log K_{\mathrm{ow}}$ and $\log K_{\text {oc }}$ values refer to [23, 27]

All the data kept a valid decimal. 
YM1 (2,168.86 ng/g), YT4 (2,141.89 ng/g), SY2 $(2,118.95 \mathrm{ng} / \mathrm{g})$, and YT2 $(2,099.17 \mathrm{ng} / \mathrm{g})$. In the wet season, the concentrations of PAHs were high in sites YT2 (4,762.97 ng/g) and YT1 (3,663.08 ng/g). In addition, the concentrations of PAHs in YT5 $(2,233.72 \mathrm{ng} / \mathrm{g})$, YM4 (2,177.16 ng/g), YM1 (2,175.39 ng/g), SY1 $(2,030.34 \mathrm{ng} / \mathrm{g}), \mathrm{GW} 1(2,022.91 \mathrm{ng} / \mathrm{g})$, and YT3 $(2,002.08$ $\mathrm{ng} / \mathrm{g}$ ) were relatively high. Site YT3 is adjacent to the roads. In dry season, a relatively high concentration of PAHs in sediment was observed at site YM1 $(5,678.46 \mathrm{ng} / \mathrm{g})$, followed by sites GW1 $(2,379.06 \mathrm{ng} / \mathrm{g})$, YM3 (a reservoir: 2,221.94 ng/g), YM2 (2,170.49 ng/g), and SY2 (2,048.98 ng/g).

\section{Partitioning PAHs in a Sediment-Water System}

The information on partitioning of pollutants is quite necessary for pollution control and quality criteria as partitioning can control the fate and distribution of pollutants in the environment [24-26]. In this study, the octanol/water partition coefficients $\left(K_{\text {ow }}\right)$ can be used for predicting the environmental fate of PAHs. The higher the $\log K_{\mathrm{ow}}$, the greater the propensity for the chemical to partition to organic phases. Apparent organic carbon normalized partition coefficients $\left(K_{\mathrm{oc}}\right)$ were applied to describe the partitioning of PAHs in a sediment-water system:

$$
K_{\mathrm{oc}}{ }^{\prime}=C_{\mathrm{s}} /\left(C_{\mathrm{w}} \times \mathrm{TOC}\right)
$$

...where $C_{\mathrm{s}}$ and $C_{\mathrm{w}}$ are monitoring PAH concentrations in water and sediment in the units of $\mathrm{ng} / \mathrm{L}$ and $\mathrm{ng} / \mathrm{g}$, TOC (unitless) is the organic carbon fraction in the sediment, and $K_{\mathrm{oc}}$ ' (unitless) is the organic carbon normalized partition coefficient for sediment-water system. The relationship between $\log K_{\text {oc }}$ and $\log K_{\text {ow }}$ were derived by Seth et al. [27] for PAHs on sediments as:

$$
\log K_{\mathrm{oc}}=1.03 \log K_{\mathrm{ow}}-0.61
$$

The TOC contents in sediments are shown in Table 2 and the calculated results are shown in Table 3. As represented in Table 3, the mean values of $\log K_{\text {oc }}$, for PAHs ranged $0.47-2.13$ in the normal season and $0.22-2.21$ in the wet season. The values of $\log K_{\text {oc }}$, varied across different sampling sites, which might be attributed to variations in $\mathrm{PAH}$ concentrations and TOC content in sediment from different sampling sites [21]. Moreover, the mean observed $\log K_{\text {oc }}$, values for PAHs were all lower than the predicted values of $\log K_{\text {oc }}$ and $\log K_{\text {ow }}$, suggesting that PAHs had the tendency to adsorb onto sediment instead of being exchanged with the water phase [28]. The differences between observed values and predicted values of $\log K_{\mathrm{oc}}$ ' for PAHs ranged 1.36-5.13 in the normal season and 1.16-5.08 in the wet season, indicating that PAHs in the sediment-water system were in a variable state. The values of $\log K_{\mathrm{oc}}$ ' for PAHs with higher molecular mass were relatively higher, indicating that PAHs with higher molecular mass had a greater tendency to adsorb onto sediment. The result is similar to our previous study.

The relationships between total PAH concentrations and TOC contents in sediments were explored. T-test was applied to evaluate the correlation, and the values of $p$ for normal and wet seasons were 0.005 and 0.000 , respectively. The values were lower than 0.05 , indicating that total $\mathrm{PAH}$ concentrations were well correlated with TOC contents in sediment. We can conclude that TOC was one of the most important factors influencing the distribution of PAHs in sediment. This result is in accordance with previous reports [29-31].

\section{Ecological Risk Assessment}

The approach of species-sensitivity distribution (SSD) was originally proposed by Kooijman [32]. Many scholars have improved the methods afterward. The SSD concept is frequently used in ecological risk assessment of pollutants in aquatic environments, which is a statistical distribution describing the variations in toxicity of a certain compound or multiple congeners to aquatic organisms [33]. For this study we choose BurrIII and ReWeibull distribution functions to fit our toxicity data. BurrIII and ReWeibull distribution functions are two flexible distributions and well-fitting to species sensitivity data. The BurrIII distribution is written as:

$$
F(x)=1 /\left[1+(b / x)^{c}\right]^{k}
$$

...where $x$ is the value of toxicity data (ug/L) and $b, c$, and $k$ are parameters.

When $k$ tends to infinity, BurrIII distribution will convert to ReWeibull distribution, which is written as:

$$
F(x)=\exp \left(-\alpha / x^{\beta}\right)
$$

...where $x$ is the value of toxicity data (ug/L) and $\alpha$ and $\beta$ are parameters.

The potential affected fractions (PAFs) of the SSD model represent the proportions of potential affected aquatic organisms to all the species. Values of PAFs greater than $5 \%$ are considered as existences of great ecological risks, while PAF values smaller than 5\% are regarded as existences of small ecological risks. In this study we applied the SSD model to assess ecological risks of individual and multiple congeners of PAHs in the water and sediment for each sampling site. Because of a lack of some parameter data, only the PAHs with parameter data were studied. The equations for calculating PAFs of individual PAHs and relative parameters are represented in Table 4.

As shown in Fig. 5, the values of PAFs for individual PAHs in water and sediment from 17 sampling sites in normal and wet seasons were all smaller than 5\%, suggesting that ecological risks of individual PAHs in water and sediment for 17 sampling sites in wet and normal seasons were unapparent. But the values of PAFs 
Table 4. SSD model parameters

\begin{tabular}{|c|c|c|}
\hline PAH & $\begin{array}{c}\text { Fitting curves of all the } \\
\text { species }\end{array}$ & $\begin{array}{c}\text { Function parameters } \\
\text { and values }\end{array}$ \\
\hline \multirow{3}{*}{ Nap } & \multirow{3}{*}{ Burr III: PAF $=1 /\left[1+(b / x)^{c}\right] k$} & $b=1560.085$ \\
\hline & & $\mathrm{c}=0.979$ \\
\hline & & $\mathrm{k}=2.708$ \\
\hline \multirow{3}{*}{ Ace } & \multirow{3}{*}{ ReWeibull: PAF $=\exp \left(-\alpha / x^{\beta}\right)$} & $\alpha=254.220$ \\
\hline & & $\beta=0.790$ \\
\hline & & $\mathrm{b}=5652.548$ \\
\hline \multirow{3}{*}{ Flo } & \multirow{3}{*}{ Burr III:PAF $=1 /\left[1+(b / x)^{c}\right]^{k}$} & $\mathrm{c}=1.292$ \\
\hline & & $\mathrm{k}=0.445$ \\
\hline & & $\mathrm{b}=492.867$ \\
\hline \multirow{3}{*}{ Phe } & \multirow{3}{*}{ Burr III: PAF $=1 /\left[1+(b / x)^{c}\right]^{k}$} & $\mathrm{c}=0.845$ \\
\hline & & $\mathrm{k}=1.080$ \\
\hline & & $b=204.144$ \\
\hline \multirow{3}{*}{ Ant } & \multirow{3}{*}{ Burr III: PAF $=1 /\left[1+(b / x)^{c}\right]^{k}$} & $\mathrm{c}=1.075$ \\
\hline & & $\mathrm{k}=0.329$ \\
\hline & & $b=67.529$ \\
\hline \multirow{3}{*}{ Fla } & \multirow{3}{*}{ Burr III: PAF $=1 /\left[1+(b / x)^{c}\right]^{k}$} & $\mathrm{c}=0.801$ \\
\hline & & $\mathrm{k}=1.412$ \\
\hline & & $\mathrm{b}=30.457$ \\
\hline \multirow{2}{*}{ Pyr } & \multirow{2}{*}{ Burr III: PAF $=1 /\left[1+(b / x)^{c}\right]^{k}$} & $\mathrm{c}=0.406$ \\
\hline & & $\mathrm{k}=1.802$ \\
\hline \multirow{2}{*}{ Bap } & \multirow{2}{*}{ ReWeibull: PAF $=\exp \left(-\alpha / x^{\beta}\right)$} & $\alpha=4.120$ \\
\hline & & $\beta=0.437$ \\
\hline
\end{tabular}

for individual PAHs from nine of the sampling sites were higher than $5 \%$ in the dry season, which means that ecological risks of those nine sites were remarkable in the dry season. In sediment, the PAF values for individual PAHs from two sampling sites were higher than $5 \%$, meaning that there were small ecological risks in the normal season, and eight sites were higher than 5\%, meaning that there were slight ecological risks in the wet season and almost no ecological risks in the dry season. In a word, in water there were almost no ecological risks in normal and wet seasons, and there were few ecological risks in the dry season in some sampling sites. In sediment, there were just two sampling sites with little ecological risks in the normal season, almost a half of sampling sites with little ecological risks in the wet season, and almost no ecological risks in the dry season.

\section{Source Identification}

Inferring the sources of PAHs is widely considered to be very important for studying the transportation and fate of pollutants in the environment. The isomer ratios are effective indicators for identifying PAH sources because the distributions of the homologues are strongly associated with the formation mechanisms of carbonaceous aerosols with similar characteristics to organic species. The ratios of the specific individual PAHs can provide information about anthropogenic sources of PAHs [34-37]. In this study, bivariate plots of Ant/(Ant + Phe) against Fla/(Fla + Pyr) were depicted in Fig. 6 to identify possible sources of PAHs in water and sediment, respectively. Ant/(Ant + Phe) ratio above 0.1 suggests the combustion origin, while ratios of Ant/(Ant + Phe) below 0.1 were indicative of a petroleum source, and ratios of Fla/(Fla + Pyr) below 0.4 were considered petrogenic sources; ratios of
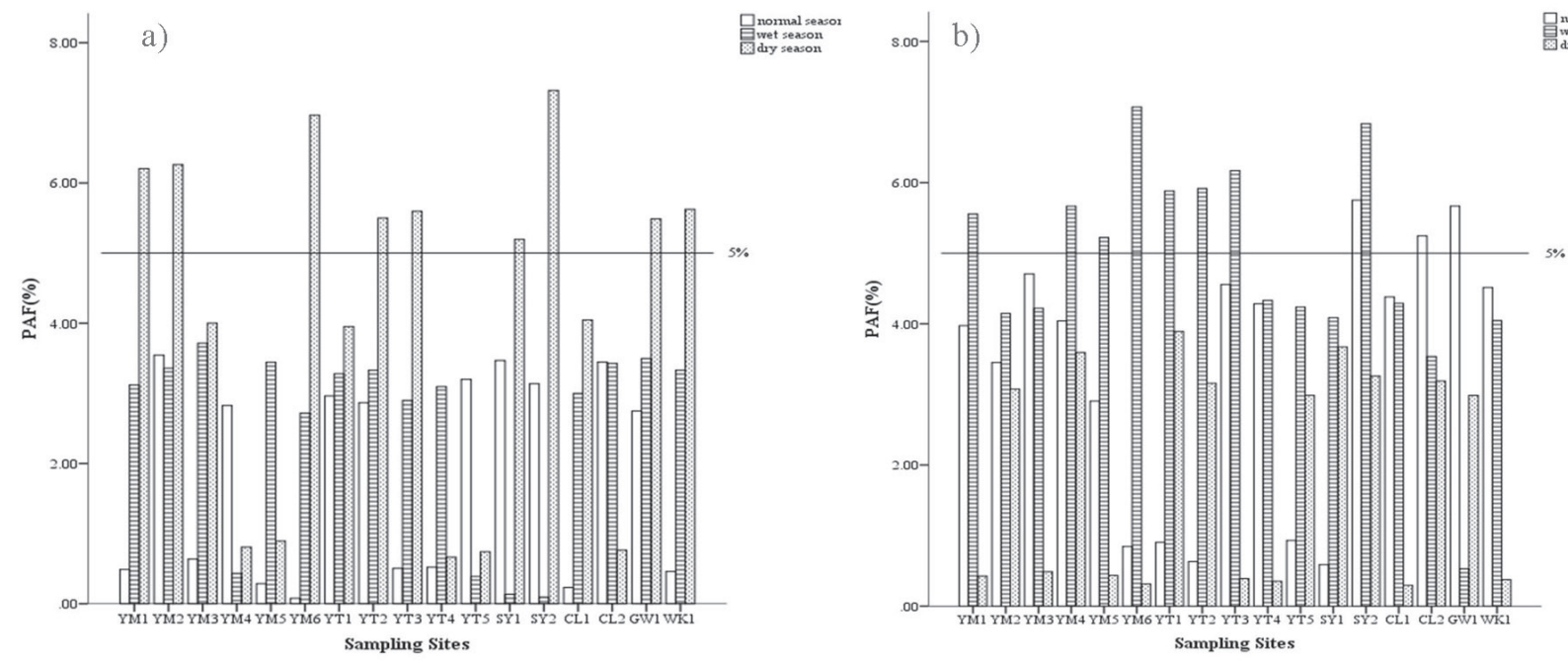

Fig. 5. Potentially affected factions (PAFs) for multiple congeners of PAHs in water a) and sediment b) from 17 sample sites in wet, normal, and dry seasons. 

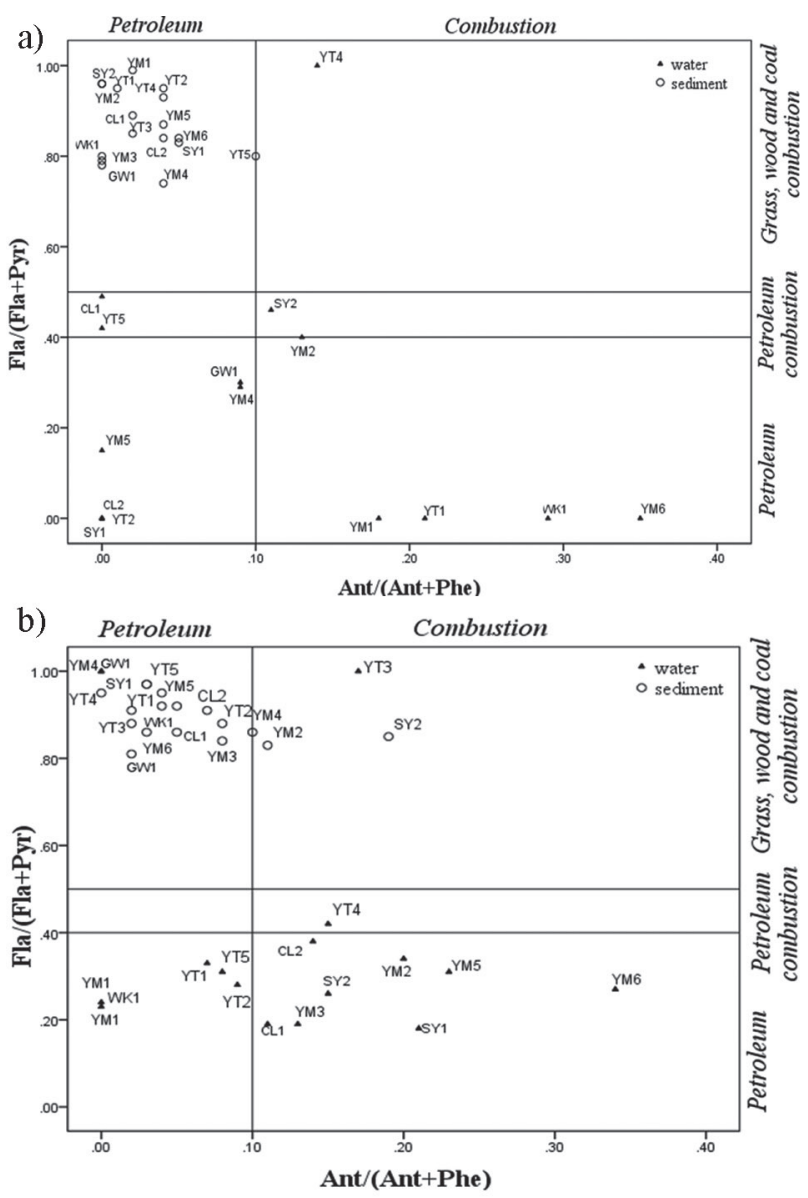

Fig. 6. Cross-plot for the diagnostic ratios of Ant/(Ant + Phe) vs. $\mathrm{Fla} /(\mathrm{Fla}+\mathrm{Pyr})$ for normal season a) and wet season b).

$\mathrm{Fla} /(\mathrm{Fla}+\mathrm{Pyr})$ between 0.4 and 0.5 represent petroleum combustion; ratios of Fla/(Fla + Pyr) greater than 0.5 were regarded as sources of grass, wood, and coal combustion [38-39].

As shown in Fig. 6, in the water samples the Ant/ (Ant+Phe) ratios varied from $0.00-0.35$ in the normal season and 0.00-0.34 in the wet season, with mean values of 0.09 and 0.12 , respectively. $53.13 \%$ of the ratios of Ant/(Ant+Phe) were above 0.1 among the two seasons, suggesting a mixed source of petroleum and combustion. The Fla/(Fla+Pyr) ratios varied from $0.00-1.00$ in the normal season and $0.18-1.00$ in the wet season, with the mean values of 0.21 and 0.41 , respectively. $71.88 \%$ of the ratios of $\mathrm{Fla} /(\mathrm{Fla}+\mathrm{Pyr})$ were below 0.4 among all water samples from this two seasons, which showed a mixed source of petroleum and combustion in the two seasons. Thus, water samples were contaminated by a mixed source of petroleum and combustion.

In the sediment samples, the Ant/(Ant+Phe) ratios varied $0.00-0.10$ in the normal season and $0.00-0.11$ in the wet season, with mean values of 0.03 and 0.06 , respectively. $88.24 \%$ of the ratios of $\mathrm{Ant} /(\mathrm{Ant}+\mathrm{Phe})$ were below 0.1 among the two seasons, suggesting a main petroleum origin. The Fla/(Fla+Pyr) ratios varied 0.74-0.99 in the normal season and 0.81-0.97 in the wet season, with mean values of 0.87 and 0.89 , respectively.
All of the ratios of Fla/(Fla+Pyr) were above 0.5 among all sediment samples from these two seasons, which showed a main origin of grass, wood, and coal combustion in the two seasons.

Compared with our previous work, in these three seasons the water samples were contaminated by a mixed source of petroleum and combustion, and the sediment samples from these two seasons showed a main origin of grass, wood, and coal combustion in the two seasons.

\section{Conclusions}

Sixteen PAHs in water and sediment from the Yinma River Basin of China in normal and wet seasons were investigated, and we refer to our previous work in the dry season. Results indicated that concentrations of PAHs in water and sediment showed spatial-temporal variations, the mean concentrations of total PAHs in water and sediment from 17 sampling sites in the wet season were both higher than in normal season, and the mean concentrations of total PAHs in the water of these two seasons were higher than in the dry seasons. But in sediment, the concentrations in the dry season were lower than in the wet season, and higher than the normal season. The results for partitioning PAHs in a sediment-water system indicated that PAHs preferably accumulated in sediment. For ecological risks, the results for the SSD model indicated that individual PAHs in water and sediment had little ecological risks in normal and wet seasons, while the ecological risks of some sites were remarkable in the dry season, and multiple congeners of PAHs in sediment from some sampling sites had ecological risks. The possible sources of 16 PAHs in water and sediment were identified as a mixture pattern of petroleum and combustion in different seasons.

\section{Acknowledgements}

This study was supported by the National Major Program of Water Pollution Control and Treatment Technology of China (2014ZX07201-011-002) and the National Natural Science Foundation of China (41371495).

\section{References}

1. ALLSHOUSE W.B., PLEIL J.D., RAPPAPORT S.M. SERRE, M. L. Mass fraction spatiotemporal geostatistics and its application to map atmospheric polycyclic aromatic hydrocarbons after 9/11. Stoch. Env. Res. Risk a, 23 (8), 1213, 2009.

2. ZHAO Z., ZHANG L., CAI Y., CHEN Y. Distribution of polycyclic aromatic hydrocarbon $(\mathrm{PAH})$ residues in several tissues of edible fishes from the largest freshwater lake in China, Poyang Lake, and associated human health risk assessment. Ecotox. Environ. Safe, 104, 323,2014.

3. GENKINGER J.M., STIGTER L., JEDRYCHOWSKI W., HUANG T., WANG S., ROEN E.L., MAJEWSKA 
R., KIELTYKA A., MROZ E., PERERA F.P. Prenatal polycyclic aromatic hydrocarbon (PAH) exposure, antioxidant levels and behavioral development of children ages 6-9. Environmental Research, 140, 136, 2015.

4. YIN F., JOHN G.F., HAYWORTH J.S., CLEMENT T.P. Long-term monitoring data to describe the fate of polycyclic aromatic hydrocarbons in Deepwater Horizon oil submerged off Alabama's beaches. Sci. Total Environ, 508, 46, 2015.

5. THEA A.E., FERREIRA D., BRUMOVSKY L.A., SCHMALKO M.E. Polycyclic aromatic hydrocarbons (PAHs) in yerba maté (Ilex paraguariensis St. Hil) traditional infusions (mate and tereré). Food Control, 60, 215, 2016.

6. PALOLUOGLU C., BAYRAKTAR H., AKTAN M., TURALIOGLU F.S., GAGA E.E. Atmospheric concentrations of polycyclic aromatic hydrocarbons (PAHs) in an urban traffic site in Erzurum, Turkey. Stoch. Env. Res. Risk a, 30 (4), 1223, 2016.

7. LIU C., LI K, YU L., XU Y., HUANG B., WU J., WANG Z. POPs and their ecological risk in sewage sludge of waste water treatment plants in Beijing, China. Stoch. Env. Res. Risk a, 27 (7), 1575, 2013.

8. YUAN H., LI T., DING X., ZHAO G., YE S. Distribution, sources and potential toxicological significance of polycyclic aromatic hydrocarbons (PAHs) in surface soils of the Yellow River Delta, China. Marine Pollution Bulletin, 83 (1), 258, 2014.

9. WANG Y., SHEN C., SHENZ., ZHANG D., CRITTENDEN J.C. Spatial variation and sources of polycyclic aromatic hydrocarbons (PAHs) in surface sediments from the Yangtze Estuary, China. Environ Sci Process Impacts, 17 (7), 1340, 2015.

10. ZHAO Z., ZHANG L., DENG J., WU J. The potential effects of phytoplankton on the occurrence of organochlorine pesticides (OCPs) and polycyclic aromatic hydrocarbons (PAHs) in water from Lake Taihu, China. Environmental Science: Processes \& Impacts, 17 (6), 1150, 2015.

11. NIEHOFF N., WHITE A.J., MCCULLOUGH L.E., STECK S.E, BEYEA J., MORDUKHOVICH I., SHEN J., NEUGUT A.I., CONWAY K., SANTELLA R.M., GAMMON M.D. Polycyclic aromatic hydrocarbons and postmenopausal breast cancer: An evaluation of effect measure modification by body mass index and weight change. Environ. Res, 152, 17, 2017.

12. HUSSAIN K., BALACHANDRAN S., RAFIQUL HOQUE R. Sources of polycyclic aromatic hydrocarbons in sediments of the Bharalu River, a tributary of the River Brahmaputra in Guwahati, India. Ecotox Environ. Safe, 122, 61, 2015.

13. LI P., CAO J., DIAO X., WANG B., ZHOU H, HAN Q., ZHENG P., LI Y. Spatial distribution, sources and ecological risk assessment of polycyclic aromatic hydrocarbons in surface seawater from Yangpu Bay, China. Mar. Pollut. Bull, 93 (1-2), 53, 2015.

14. PARSONS M.J., LONG D.T., GIESY J.P., KANNAN K. Inferring sources for mercury to inland lakes using sediment chronologies of polycyclic aromatic hydrocarbons. Environ Sci Process Impacts, 16 (9), 2108, 2014.

15. QU C., LI B., WU H., WANG S., LI F. Probabilistic ecological risk assessment of heavy metals in sediments from China's major aquatic bodies. Stoch. Env. Res. Risk a, 30 (1), 271, 2016.

16. YU W., LIU R., XU F., SHEN Z. Environmental risk assessments and spatial variations of polycyclic aromatic hydrocarbons in surface sediments in Yangtze River Estuary, China. Marine Pollution Bulletin, 100 (1), 507, 2015.
17. CHEN C.W., CHEN C.F., DONG C.D., TU Y.T. Composition and source apportionment of PAHs in sediments at river mouths and channel in Kaohsiung Harbor, Taiwan. J Environ Monit, 14 (1), 105, 2012.

18. GUO W., ZHANG H., CUI S., XU Q., TANG Z., GAO F. Assessment of the distribution and risks of organochlorine pesticides in core sediments from areas of different human activity on Lake Baiyangdian, China. Stoch. Env. Res. Risk a, 28 (4), 1035, 2014.

19. ZHENG B., WANG L., LEI K., NAN B. Distribution and ecological risk assessment of polycyclic aromatic hydrocarbons in water, suspended particulate matter and sediment from Daliao River estuary and the adjacent area, China. Chemosphere, 149, 91, 2016.

20. CUI S., FU Q., LI T., MA W., LIU D., WANG M. SedimentWater Exchange, Spatial Variations, and Ecological Risk Assessment of Polycyclic Aromatic Hydrocarbons (PAHs) in the Songhua River, China. Water, 8 (3348), 2016.

21. QIN N., HE W., KONG X., LIU W., HE Q., YANG B., WANG Q., YANG C., JIANG Y., JORGENSEN S.E., XU F., ZHAO X. Distribution, partitioning and sources of polycyclic aromatic hydrocarbons in the water-SPMsediment system of Lake Chaohu, China. Sci. Total Environ, 496, 414, 2014.

22. YANG W., LANG Y., LI G. Cancer risk of polycyclic aromatic hydrocarbons (PAHs) in the soils from Jiaozhou Bay wetland. Chemosphere, 112, 289, 2014.

23. SUN C., ZHANG J., MA Q., CHEN Y., JU H. Polycyclic aromatic hydrocarbons (PAHs) in water and sediment from a river basin: sediment-water partitioning, source identification and environmental health risk assessment. Environ. Geochem. Hlth, 39 (1), 63, 2017.

24. LATIMER J.S., DAVIS W.R., KEITH D.J. Mobilization of PAHs and PCBs from In-Place Contaminated Marine Sediments During Simulated Resuspension Events. Estuarine, Coastal and Shelf Science, 49 (4), 577, 1999.

25. OLOLADE I.A., OLADOJA N.A., LAJIDE L., OLOLADE O.O., EJELONU B.C., AKINNIFESI T.A., ALAREMU A.G. Partitioning of polycyclic aromatic hydrocarbons in sediment and porewater from Ondo coastal area, Nigeria. The Environmentalist, 32 (4), 363, 2012.

26. SHI G., TIAN Y., GUO C., FENG Y., XU J., ZHANG Y. Sediment-pore water partition of PAH source contributions to the Yellow River using two receptor models. J. Soil. Sediment, 12 (7), 1154, 2012.

27. SETH R., MACKAY D., MUNCKE J. Estimating the organic carbon partition coefficient and its variability for hydrophobic chemicals, Environ. Sci. Technol. 33 (14), 2390, 1999.

28. GUO W., HE M., YANG Z., LIN C., QUAN X., MEN B. Distribution, partitioning and sources of polycyclic aromatic hydrocarbons in Daliao River water system in dry season, China. Journal of Hazardous Materials, 164 (2-3), 1379, 2009.

29. KANG Y., WANG X., DAI M., FENG H. LI A., SONG Q. Black carbon and polycyclic aromatic hydrocarbons (PAHs) in surface sediments of China's marginal seas. Chinese Journal of Oceanology and Limnology, 27 (2), 297, 2009.

30. QI W., QU J., LIU H., HU C., LAN H., REN H., XU W. Partitioning and sources of PAHs in wastewater receiving streams of Tianjin, China. Environmental Monitoring and Assessment, 184 (4), 1847, 2012.

31. ZHANG J., SEQUARIS J.M., KLUMPP E. Effects of natural organic matter on the microporous sorption sites of black carbon in a Yangtze River sediment. Environ. Sci. Pollut. R, 20 (10), 6992, 2013. 
32. KOOIJMAN SALM A safety factor for LC50 values allowing for differences in sensitivity among species. Water Res, 21, 269, 1987.

33. WHEELER J.R., GRIST E.P.M., LEUNG K.M.Y., Morritt D., CRANE M. Species sensitivity distributions: data and model choice. Marine Pollution Bulletin, 45 (1-12), 192, 2002.

34. BUDZINSKI H., JONES I., BELLOCQ J., PIÉRARD C., GARRIGUES P. Evaluation of sediment contamination by polycyclic aromatic hydrocarbons in the Gironde estuary. Mar. Chem, 58 (1-2), 85, 1997.

35. QIAO M., WANG C., HUANG S., WANG D., WANG Z. Composition, sources, and potential toxicological significance of PAHs in the surface sediments of the Meiliang Bay, Taihu Lake, China. Environment International, 32 (1), 28, 2006.

36. ZHU Y., YANG L., YUAN Q., YAN C., DONG C., MENG C., SUI X., YAO L., YANG F., LU Y., WANG W. Airborne particulate polycyclic aromatic hydrocarbon (PAH) pollution in a background site in the North China Plain: Concentration, size distribution, toxicity and sources. Sci. Total Environ, 466-467, 357, 2014.

37. SUMAN S., SINHA A., TARAFDAR A. Polycyclic aromatic hydrocarbons (PAHs) concentration levels, pattern, source identification and soil toxicity assessment in urban traffic soil of Dhanbad, India. Sci. Total Environ, 545-546, 353, 2016.

38. YUNKER M.B., MACDONALD R.W., VINGARZAN R., MITCHELL R. H, GOYETTE D, SYLVESTRE S. PAHs in the Fraser River basin: a critical appraisal of PAH ratios as indicators of PAH source and composition. Org. Geochem, 33 (4), 489, 2002.

39. SCHIFMAN L.A., BOVING T.B. Spatial and seasonal atmospheric PAH deposition patterns and sources in Rhode Island. Atmos. Environ, 120, 253, 2015. 